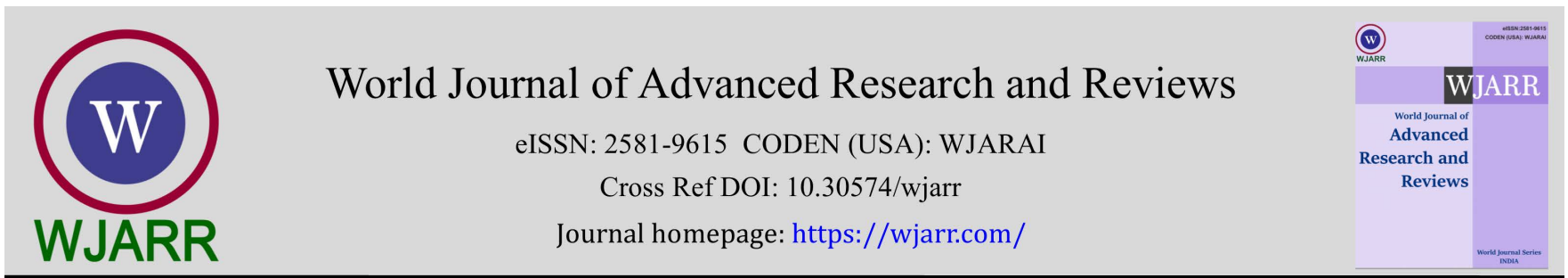

(RESEARCH ARTiClE)

Check for updates

\title{
Physicochemical properties, total hydrocarbon content, and trace metals of water and sediments from major River Estuaries within the Niger Delta Region of Nigeria
}

\author{
Godwin Asukwo Ebong 1,* and Richard Christopher John ${ }^{2}$ \\ ${ }^{1}$ Department of Chemistry, University of Uyo, P. M. B 1017, Uyo. Nigeria. \\ 2 Department of Microbiology, University of Uyo, P. M. B 1017, Uyo. Nigeria.
}

World Journal of Advanced Research and Reviews, 2021, 12(02), 587-597

Publication history: Received on 22 October 2021; revised on 26 November 2021; accepted on 28 November 2021

Article DOI: https://doi.org/10.30574/wjarr.2021.12.2.0650

\begin{abstract}
Water and sediment samples from Cross River, Imo River, and Qua Iboe River Estuaries were collected and treated using standard analytical procedures. The samples were analyzed for their physicochemical properties, total hydrocarbon content (THC), and trace metals. Results obtained revealed that, the mean levels of total suspended solids (TSS), total dissolved solids (TDS), turbidity, colour, biochemical oxygen demand (BOD), THC, cadmium (Cd), iron (Fe), nickel (Ni), lead $(\mathrm{Pb})$, and zinc $(\mathrm{Zn})$ in water were higher than their acceptable limits in Nigeria. Whereas, the mean levels water $\mathrm{pH}$, electrical conductivity (EC), dissolved oxygen (DO), nitrate, sulphate, phosphate, and copper (Cu) were within their acceptable limits. The results obtained also revealed that, the mean levels of nitrate, THC, and Fe in sediments were higher than their recommended limits. While the levels of $\mathrm{pH}, \mathrm{EC}$, sulphate, phosphate, $\mathrm{Cd}, \mathrm{Cu}, \mathrm{Ni}, \mathrm{Pb}, \mathrm{and} \mathrm{Zn}$ in sediments were within their recommended limits. This study indicated that the anthropogenic activities by oil and oilrelated companies within the Niger Delta Region of Nigeria may have contributed significantly to the high level of toxic substances in the water channels within the zone. The results obtained revealed that, the direct or indirect exposure to untreated water from the studied water channels may result in serious health challenges. Hence, the environment should be closely monitored to forestall a devastating situation in the region.
\end{abstract}

Keywords: Water pollution; Trace Metals; Physicochemical Properties; Niger Delta Region; Estuary; Nigeria

\section{Introduction}

Water is one of the major six (6) classes of food needed by all biological systems including human. However, when human beings are exposed to a highly contaminated water either directly or indirectly it becomes harmful. The oil exploration and exploitation activities within the Niger Delta Area of Nigeria has contributed significantly to the accumulation of toxic substances in the aquatic ecosystem within the region. Studies have revealed the high levels of toxic substances in water bodies within the Niger Delta Region of Nigeria [1, 2,3,4,5]. Nwidu et al. [6] has also revealed that, the health status of people in a community depends significantly on the quality of water within the community. Studies have shown that most deaths within the developing nations of the world are caused by water related diseases [7, 8]. According to Shyamala et al. [9] contaminated water bodies are channels for transmitting disease causing organisms and deadly chemicals into the human system. Some metals are essential for human but all metals are potentially harmful to most living things including human at levels higher their recommended limits [10]. It has been reported that about 3.4 million deaths every year mostly children are attributed to water-related diseases [11]. The consumption of aquatic foods obtained from a contaminated aquatic ecosystem is a death trap for the consumers [12]. The interaction between the studied rivers and the Atlantic Ocean at the estuary might also elevate the contaminants in these water channels.

\footnotetext{
${ }^{*}$ Corresponding author: Godwin Asukwo Ebong

Department of Chemistry, University of Uyo, P. M. B 1017, Uyo. Nigeria.
}

Copyright (c) 2021 Author(s) retain the copyright of this article. This article is published under the terms of the Creative Commons Attribution Liscense 4.0. 
Sediments in water bodies within the Niger Delta Region also accumulate high levels of contaminants and discharge them later into the water channels [13]. The contamination and subsequent pollution of sediments is a serious environmental problem since aquatic organisms may bioaccumulate these pollutants and transfer them into human body through food chain $[14,15,16]$. It has also been established that, exposure to water and aquatic organisms from a contaminated water body could be very harmful to human health $[17,18]$. Consequently, monitoring of aquatic water channels within the Niger Delta Region should be done regularly. This study was undertaken to ascertain the safety or otherwise of these water bodies and sea foods harvested from them. The activities of crude oil and related companies has made it a necessity for the regular monitoring of the water quality within the Niger Delta area of Nigeria.

\section{Material and methods}

\subsection{Study Area}

Cross River Estuary lies between latitudes of $4^{\circ} 12$ ! and $5^{\circ} 14^{\prime} \mathrm{N}$ and longitudes $8^{\circ} 10^{\prime}$ and $8^{\circ} 42^{\prime}$ E. The Cross River originates from the Cameroun mountains and moves southwards into Nigeria where it empties into the Atlantic Ocean at the Gulf of Guinea. Qua Iboe River Estuary lies within latitudes $4^{\circ} 30^{\prime}$ to $4^{\circ} 45^{\prime} \mathrm{N}$ and longitudes $7^{\circ} 30^{\prime}$ to $8^{\circ} 00^{\prime} \mathrm{E}$ on the south eastern Nigerian shoreline. It originated from Umuahia Hills in Abia State and traverses through sedimentary terrains before emptying into the Atlantic Ocean. The Imo River Estuary is within latitudes $4^{\circ} .35^{\prime}$ to $4^{\circ} 46^{\prime}$ and longitudes $7^{\circ} 21^{\prime}$ to $7^{\circ} 43^{\prime}$. The river originated from Okigwe in Imo State, Nigeria and moves southwards into the Atlantic Ocean at the Bight of Bonny. These river estuaries are brackish water which have been impacted negatively by the oil exploration and exploitation activities within the Niger Delta Region of Nigeria. They are also used for water transportation and fishing activities. The study area has two separate seasons (dry and wet), the dry season lasts from the last week of November or early December to early March. The wet seasons has a longer period from mid-March to the end of November [19].

\subsection{Sample Collection, Treatment, and Analysis}

Water and sediment samples were obtained at Cross River, Imo River, and Qua Iboe River Estuaries between October and December, 2000. At each of the estuaries, samples were collected at three (3) designated points and mixed together to from a composite sample for that location. The collection and treatment of water samples were done following the procedures of APHA [20,21].

The surface sediment samples were also collected at the same locations where water samples were collected using Grab Sampler using the methods of USEPA [22].

Sediment samples were air dried for three (3) days, ground and sieved with a 2mm mesh (USEPA, 2001). One gram (1g) each of the dried sediment was digested with Aqua-regia on a hot plate following the procedures of USEPA [23].

The $\mathrm{pH}$ of the samples was determined using $\mathrm{pH}$ meter following the procedures of APHA [20], while the turbidity, colour, and electrical conductivity were analyzed for using nephelometer, photometer, and conductivity meter, respectively [21]. The total suspended solids (TSS) and total dissolved solids (TDS) were determined by the filtration method following the methods of USEPA [24]. Water samples for DO, BOD, and nitrate analyses were collected and treated according to the procedures of APHA $[21,25,26]$. The nutrients (anions) in the water samples were determined by spectrophotometric methods as described by APHA [20]. The total hydrocarbon content (THC) in samples were obtained spectrophotometrically using the methods of ASTM [27]. The total concentrations of all the trace metals analyzed for in water and sediments was determined using an Agilent 710 inductively coupled plasma optical emission spectrometer (ICP-OES) following the methods of USEPA [28].

\section{Results and discussion}

\subsection{Physicochemical Properties of Water from the studied River Estuaries.}

The results for the physicochemical properties, nutrients, total hydrocarbon content, and trace metals in water samples from the studied river estuaries are indicated in Table 1.

As shown in Table 1, the $\mathrm{pH}$ of the studied water channels range of 6.84 to 7.14 with a mean value of $6.95 \pm 0.13$. This range is higher than $4.70-6.50$ reported by Akpan [29] in water body within the studied area. The pH range obtained in this study is favourable for optimal aquatic life [30]. The reported range is also within the acceptable limit of $6.5-8.5$ by NESREA [31]. Consequently, the human activities within the studied rivers may not have affected the pH levels of 
these water channels. Hence, the $\mathrm{pH}$ of these water bodies may not affect neither the aquatic nor human beings exposed to these water bodies.

The total suspended solids (TSS) of the studied river estuaries varied between 17.72 and $23.25 \mathrm{mg} / \mathrm{l}$ with a level of $20.67 \pm 2.27 \mathrm{mg} / \mathrm{l}$. This range is lower than 12.55 - $49.57 \mathrm{mg} / \mathrm{l}$ reported by Anhwange et al. [32]. However, the mean TSS value is higher than $0.75 \mathrm{mg} / \mathrm{l}$ recommended by NESREA [31] for an unpolluted water. Thus, the TSS contents of the studied water channels may have a negative effect on the aquatic life of the studied water channels. Similarly, the activities within these water bodies may have elevated their TSS contents.

The levels of total dissolved solids (TDS) in the studied river estuaries indicates a range of $558.53-654.10 \mathrm{mg} / \mathrm{l}$ with a mean value of $611.70 \pm 38.75 \mathrm{mg} / \mathrm{l}$. The obtained range is higher than $120.00-143.7 \mathrm{mg} / \mathrm{l}$ reported by Ukpong and Peter [33]. The mean value of TDS obtained is also higher than $500.0 \mathrm{mg} / \mathrm{l}$ recommended for unpolluted water by NESREA [31]. Hence, human and activities within these water bodies may have elevated their TDS levels. Consequently, human beings exposed to these water channels may experience cancer, arteriosclerotic heart disease, and cardiovascular disease [34].

The values recorded for turbidity in this study varied from 74.80 to $110.36 \mathrm{mg} / \mathrm{l}$ with a mean concentration of $94.16 \pm 14.69$ NTU. The reported range is higher than $76.00-96.70$ NTU obtained by Ebigwai et al. [35]. The mean value obtained is also higher than 5.0 NTU stipulated by NESREA [31] for an unpolluted water. Consequently, the anthropogenic activities in the study area may have attributed to the high levels of turbidity reported. The high turbidity of these water bodies is harmful to those exposed to these water bodies because according to Reza and Singh [36] high turbidity in water is directly related to high disease-causing microorganisms.

The studied river estuaries exhibited colour intensity between 39.04 and $48.62 \mathrm{Hu}$. This

obtained range is lower than $4.00-402.20 \mathrm{Hu}$ reported by Anhwange et al. [32]. However, the mean value obtained $(44.52 \pm 4.03 \mathrm{Hu})$ is higher than $15.0 \mathrm{Hu}$ recommended for potable water by NESREA (2011). The levels of colour recorded in the studied river estuaries could be attributed to the high TDS and turbidity contents of the water channels [37]. As a consequence of this, these water bodies may not be suitable for domestic use based on their high levels of contaminants.

Electrical conductivity (EC) of the studied river estuary ranged from 443.35 to $574.13 \mu \mathrm{S} / \mathrm{cm}$. This range is higher than $16.40-64.40 \mu \mathrm{S} / \mathrm{cm}$ obtained by Ugbaja and Ephraim [38]. Nevertheless, the mean value of EC obtained in this research $(526.18 \pm 58.81 \mu \mathrm{S} / \mathrm{cm})$ is lower than the $1000.0 \mu \mathrm{S} / \mathrm{cm}$ limit recommended for water by NESREA [31]. Hence, the values of EC in the studied water channels may not affect the ecosystem negatively.

The dissolved oxygen (DO) which indicates the healthy nature of a water body with respect to organic wastes varied between 3.64 and $3.82 \mathrm{mg} / \mathrm{l}$. This range is lower than $4.0-5.4 \mathrm{mg} / \mathrm{l}$ reported by Simeon et al. [39]. The mean value of D0 obtained in the studied river estuaries $(3.74 \pm 0.08 \mathrm{mg} / \mathrm{l})$ is lower than $4.0 \mathrm{mg} / \mathrm{l}$ recommended for a healthy water system by NESREA [31]. Consequently, the river estuaries may have been highly contaminated by biodegradable wastes due to anthropogenic activities in the area and the interactions of these rivers with the Atlantic Ocean at the estuary. This low level of DO may have impact on the survival of fishes, photosynthetic process, nutrients availability and growth of microorganisms $[40,41]$.

Biochemical Oxygen Demand (BOD) of a water channel indicates the level of oxygen required by microorganisms to decompose organic waste under aerobic conditions. The BOD of the studied river estuaries ranged from 6.42 to 6.76 $\mathrm{mg} / \mathrm{l}$ with a mean value of $6.59 \pm 0.14 \mathrm{mg} / \mathrm{l}$. The range of BOD reported is higher than $2.75-3.74 \mathrm{mg} / \mathrm{l}$ obtained by Etesin et al. [42]. However, the mean value is higher than $6.0 \mathrm{mg} / \mathrm{l}$ recommended for an unpolluted water by NESREA [31]. This is an indication of high level of biodegradable wastes and nutrients in these water channels thus, these water bodies are unsuitable for human consumption [43]. The high BOD values reported may be attributed to the natural and anthropogenic activities at the estuaries.

\subsection{Distribution of Nutrients in the studied River Estuaries.}

The level of nitrate in the studied water channels ranged from 28.44 to $41.27 \mathrm{mg} / \mathrm{l}$ (Table 1). This range is higher than $4.2-5.7 \mathrm{mg} / \mathrm{l}$ reported by Simeon et al. [39]. The mean value of nitrate obtained ( $36.77 \pm 5.90 \mathrm{mg} / \mathrm{l})$ is lower than the recommended limit of $40.0 \mathrm{mg} / \mathrm{l}$ for unpolluted water by NESREA [31]. However, the mean values of nitrate obtained for Imo and Qua Iboe River Estuaries were higher than the recommended limit. The high values of nitrate reported may be attributed to anthropogenic activities with the studied locations. Studies have shown that, high levels of nitrate in 
water may lead to blue-eye syndrome in children and pregnant women [44]. Thus, untreated water from the studied channels may not be fit for human consumption.

Sulphate concentrations in the studied river estuaries varied from 68.82 to $100.95 \mathrm{mg} / \mathrm{l}$. These values are higher than $0.05-23.19 \mathrm{mg} / \mathrm{l}$ reported by Ebigwai et al. [35]. However, the mean value of sulphate $(86.40 \pm 13.29 \mathrm{mg} / \mathrm{l})$ obtained is lower $500.0 \mathrm{mg} / \mathrm{l}$ recommended for unpolluted water by NESREA [31]. Subsequently, the levels of sulphate in the studied water channels may not be harmful to both human health and aquatic life.

The levels of phosphate in the studied river estuaries varied between 1.37 and $3.11 \mathrm{mg} / \mathrm{l}$. The reported range is lower than 2.144 to $9.741 \mathrm{mg} / \mathrm{l}$ by Isiuku and Enyoh [45]. The mean value of phosphate recorded $(2.45 \pm 0.77 \mathrm{mg} / \mathrm{l})$ is also lower than the limit recommended for unpolluted water $(3.5 \mathrm{mg} / \mathrm{l})$ by NESREA [31]. This is an indication that, the natural and anthropogenic activities within the studied estuaries may not have affected the phosphate content significantly. Hence, the phosphate content of the studied water channels may not have serious impact on both human and aquatic animals exposed to these aquatic ecosystems.

\subsection{Total Hydrocarbon Content of Water from the studied River Estuaries.}

The total hydrocarbon content (THC) of the studied river estuaries varied from 6.89 to $13.08 \mathrm{mg} / \mathrm{l}$ with a mean value of $10.07 \pm 2.53 \mathrm{mg} / \mathrm{l}$. These values are lower than $15.6-23.4 \mathrm{mg} / \mathrm{l}$ of THC in surface water reported by Wokoma [46]. The mean value obtained is higher than $10.0 \mathrm{mg} / \mathrm{l}$ recommended for an unpolluted water channel by NESREA [31]. Consequently, the THC of the studied water channels may have been affected negatively by the crude oil activities within the area. However, the mean level of THC Cross River Estuary $(6.89 \mathrm{mg} / \mathrm{l})$ is within the acceptable limit. THC of a water channel has direct impact on the availability of oxygen for aquatic organisms hence, the values reported may reduce the growth of aquatic plants and animals significantly [47].

\subsection{Distribution of Trace Metals in Water from the studied River Estuaries.}

The results in Table 1 show a range and a mean concentration for cadmium (Cd) as $0.12-0.16 \mathrm{mg} / \mathrm{l}$ and $0.14 \pm 0.02 \mathrm{mg} / \mathrm{l}$, respectively. The obtained range is higher than $0.01-0.02 \mathrm{mg} / \mathrm{l}$ reported by Ebigwai et al. [35]. The mean is also higher than $0.01 \mathrm{mg} / \mathrm{l}$ recommended limit for $\mathrm{Cd}$ in unpolluted water by NESREA [31]. Consequently, the anthropogenic activities within the studied river estuaries may have elevated the levels of $\mathrm{Cd}$ in the water channels. $\mathrm{Cd}$ is a toxic metal even at a very low concentration to both higher and the lower animal [48]. Consequently, human beings exposed to untreated water from these channels may be at risk of liver, kidneys, pancreas and spleen problems [49].

The results for copper $(\mathrm{Cu})$ concentrations in the studied river estuaries ranged from 0.87 to $1.69 \mathrm{mg} / \mathrm{l}$. This range is higher than $0.0011-0.0630 \mathrm{mg} / \mathrm{l}$ reported in surface water by Nwineewii and Edem [50]. The mean value concentration obtained $(1.23 \pm 0.34 \mathrm{mg} / \mathrm{l})$ is lower than $2.0 \mathrm{mg} / \mathrm{l} \mathrm{recommended} \mathrm{for} \mathrm{unpolluted} \mathrm{water} \mathrm{by} \mathrm{WHO} \mathrm{[11].} \mathrm{Accordingly,} \mathrm{the}$ studied water channels may not pose any serious risk associated with $\mathrm{Cu}$ toxicity to the aquatic environment and human exposed to the water.

Iron $(\mathrm{Fe})$ concentrations in the studied river estuaries ranged from 5.06 to $13.25 \mathrm{mg} / \mathrm{l}$. The range reported is lower than $0.025-122.10 \mathrm{mg} / \mathrm{l}$ recorded by Jonah et al. [51]. The mean Fe concentration obtained $(9.90 \pm 3.50 \mathrm{mg} / \mathrm{l})$ is higher than $0.5 \mathrm{mg} / \mathrm{l}$ stipulated for unpolluted water by NESREA [31]. Thus, the anthropogenic activities within the studied estuaries may have resulted in elevating the levels of Fe in these water channels. Consequently, this may result in risk associated with pathogenic organisms; since the organisms' requirement Fe for their optimal growth [52].

The results in Table 1 indicate a range and mean value of nickel $(\mathrm{Ni})$ as $0.74-1.02 \mathrm{mg} / \mathrm{l}$ and $0.90 \pm 0.12$, respectively. The range of Ni reported in this study is higher than $0.19-0.29 \mathrm{mg} / \mathrm{l}$ obtained by Elemile et al. [53]. The mean value of $\mathrm{Ni}$ obtained is also higher than $0.10 \mathrm{mg} / \mathrm{l}$ limit recommended for unpolluted water by NESREA [31]. Therefore, the human activities around these estuaries may have resulted in the elevated Ni levels reported. Hence, human beings exposed to unpolluted water from the studied locations over time may could be at a risk of suffering cancer [54].

Lead $(\mathrm{Pb})$ in the studied water channels ranged between 1.02 and $1.63 \mathrm{mg} / \mathrm{l}$ with a mean value of $1.40 \pm 0.27 \mathrm{mg} / \mathrm{l}$. This range is higher than $0.01-0.61 \mathrm{mg} / \mathrm{l}$ reported by Oribhabor and Ogbeibu [55] in surface water. The mean value of $\mathrm{Pb}$ obtained in this study is higher than $0.1 \mathrm{mg} / \mathrm{l}$ recommended for unpolluted water by NESREA [31]. The high levels of $\mathrm{Pb}$ obtained could be attributed to the anthropogenic activities within the studied water channels. According to Cleveland et al. [56] human exposure to untreated water from these channels may results in depression, nausea, and abdominal pain, loss of coordination, vomiting, diarrhea, and anemia. 
The concentrations of zinc ( $\mathrm{Zn}$ ) in the studied water channels varied from 2.13 to $3.41 \mathrm{mg} / \mathrm{l}$. The obtained range is consistent with the range reported by Ebong and Etuk [8] but higher than $0.0197-0.2140 \mathrm{mg} / \mathrm{l}$ obtained by Nwineewii and Edem [50]. The mean concentration of Zn reported (3.31 \pm 0.11 ) is higher than the safe limit of $3.0 \mathrm{mg} / \mathrm{l}$ by NESREA [31]. Hence, the human beings exposed to untreated water from these estuaries may be at risk of Zn toxicity and its attendants' health implications [57]. The high levels of Zn reported in the studied areas may also have negative impact on the growth of aquatic plants and animals [58, 59].

Table 1 Physicochemical properties and Trace metals in water from Cross River, Imo, and Qua Iboe River Estuaries

\begin{tabular}{|c|c|c|c|c|c|c|c|c|c|}
\hline$S / N$ & Parameter & $\begin{array}{l}\text { Cross } \\
\text { River } \\
\text { Estuary }\end{array}$ & $\begin{array}{l}\text { Imo } \\
\text { River } \\
\text { Estuary }\end{array}$ & $\begin{array}{l}\text { Qua Iboe } \\
\text { River } \\
\text { Estuary }\end{array}$ & Min & Max & Mean & SD & $\begin{array}{l}\text { Acceptable } \\
\text { Standard }\end{array}$ \\
\hline 1 & $\mathrm{pH}$ & 6.87 & 6.84 & 7.14 & 6.84 & 7.14 & 6.95 & 0.13 & $6.5-8.5$ \\
\hline 2 & TSS & 17.72 & 21.05 & 23.25 & 17.72 & 23.25 & 20.67 & 2.27 & 0.75 \\
\hline 3 & TDS & 558.53 & 654.10 & 622.48 & 558.53 & 654.10 & 611.70 & 38.75 & 500.0 \\
\hline 4 & Turbidity & 74.80 & 110.36 & 97.31 & 74.80 & 110.36 & 94.16 & 14.69 & 5.0 \\
\hline 5 & Colour & 39.04 & 48.62 & 45.90 & 39.04 & 48.62 & 44.52 & 4.03 & 15.0 \\
\hline 6 & EC & 443.35 & 561.06 & 574.13 & 443.35 & 574.13 & 526.18 & 58.81 & 1000.0 \\
\hline 7 & DO & 3.77 & 3.82 & 3.64 & 3.64 & 3.82 & 3.74 & 0.08 & 4.0 \\
\hline 8 & BOD & 6.58 & 6.76 & 6.42 & 6.42 & 6.76 & 6.59 & 0.14 & 6.0 \\
\hline 9 & THC & 6.89 & 10.24 & 13.08 & 6.89 & 13.08 & 10.07 & 2.53 & 10.0 \\
\hline 10 & Nitrate & 28.44 & 41.27 & 40.61 & 28.44 & 41.27 & 36.77 & 5.90 & 40.0 \\
\hline 11 & Sulphate & 68.82 & 100.95 & 89.43 & 68.82 & 100.95 & 86.40 & 13.29 & 500.0 \\
\hline 12 & Phosphate & 1.37 & 3.11 & 2.87 & 1.37 & 3.11 & 2.45 & 0.77 & 3.5 \\
\hline 13 & Cadmium & 0.12 & 0.16 & 0.14 & 0.12 & 0.16 & 0.14 & 0.02 & 0.01 \\
\hline 14 & Copper & 0.87 & 1.13 & 1.69 & 0.87 & 1.69 & 1.23 & 0.34 & 2.0 \\
\hline 15 & Iron & 5.06 & 11.38 & 13.25 & 5.06 & 13.25 & 9.90 & 3.50 & 0.5 \\
\hline 16 & Nickel & 0.74 & 0.95 & 1.02 & 0.74 & 1.02 & 0.90 & 0.12 & 0.1 \\
\hline 17 & Lead & 1.02 & 1.54 & 1.63 & 1.02 & 1.63 & 1.40 & 0.27 & 0.1 \\
\hline 18 & Zinc & 3.16 & 3.37 & 3.41 & 3.16 & 3.41 & 3.31 & 0.11 & 3.0 \\
\hline
\end{tabular}

TSS = Total suspended solids; TDS = Total dissolved solids; EC = Electrical conductivity; DO = Dissolved oxygen; BOD = Biochemical oxygen demand; THC = Total hydrocarbon content; Min = Minimum; Max = Maximum; SD = Standard deviation

\subsection{Physicochemical Properties in Sediments from the studied River Estuaries}

Results for the physicochemical properties, nutrients, total hydrocarbon content and trace metals in sediments from the studied river estuaries are shown in Table 2.

The $\mathrm{pH}$ of sediments from the studied river estuaries varied between 6.58 to 6.69 . This range is lower than $7.18-7.28$ reported in sediments by Simeon et al. [39]. The obtained range of $\mathrm{pH}$ is also within the acceptable range of $6.5-8.5$ by WHO [60]. Thus, the pH levels of sediments from the studied river estuaries may not have adverse effect on the chemistry of the river channels.

The electrical conductivity (EC) of sediments from the studied river channels ranged from 554.74 to $573.62 \mu \mathrm{S} / \mathrm{cm}$. This EC range is consistent with that reported by Adesuyi et al. [61] but lower than $40.0-1940.0 \mathrm{uS} / \mathrm{cm}$ obtained by Ezekiel et al. [62]. The mean EC value obtained $(565.49 \pm 7.93 \mu \mathrm{S} / \mathrm{cm})$ is within the safe limit of $1500.0 \mu \mathrm{S} / \mathrm{cm}$ by WHO [60]. The low level of EC values in the studied sediments may be attributed to the levels of ions within the studied water channels. 


\subsection{Distribution of Nutrients in Sediments from the studied River Estuaries.}

Nitrate levels in the studied sediments varied from 57.54 to $68.28 \mathrm{mgkg}^{-1}$ with a mean value of $63.78 \pm 4.56 \mathrm{mgkg}^{-1}$. This range is lower than $1.34-4.0 \mathrm{mgkg}^{-1}$ reported in sediments by Wokoma and Friday [63]. The mean value reported is also higher than $40.0 \mathrm{mgkg}^{-1}$ recommended limit for nitrate by WHO [60] in unpolluted water. The high levels of nitrate reported in sediments from the studied estuaries could be attributed to the anthropogenic activities within the study area. Hence, exposure to these water channels may results in blue-eye syndrome in children and pregnant women [44]. The high nitrate content of these water channels may also cause eutrophication [64].

The sulphate content of the studied sediments varied between 83.72 and $89.56 \mathrm{mgkg}^{-1}$. The range reported is higher than $1.06-3.81 \mathrm{mgkg}^{-1}$ obtained by Seiyaboh et al. [65]. The mean value of sulphate obtained $\left(86.92 \pm 2.42 \mathrm{mgkg}^{-1}\right)$ is also lower than $240.0 \mathrm{mgkg}^{-1}$ recommended limit for unpolluted sediment by WHO [60]. Hence, the studied sediments may not have been polluted by the sulphate content.

Phosphate content of sediments from the studied river estuaries ranged from 2.71 to $3.54 \mathrm{mgkg}^{-1}$ with a mean value of $3.18 \pm 0.35 \mathrm{mgkg}^{-1}$. The reported range is lower than $5.6-16.89 \mathrm{mgkg}^{-1}$ obtained in sediments by Adesuyi et al. [61]. Nevertheless, the mean value recorded is within the safe limit of $5.0 \mathrm{mgkg}^{-1}$ by WHO [60]. Thus, the water channel may not have been polluted by phosphate and may not experience eutrophication.

\subsection{Total Hydrocarbon Content in Sediments from the studied River Estuaries.}

The total hydrocarbon content (THC) of sediments from the studied river estuaries indicated a range and a mean value of $32.04-61.85 \mathrm{mgkg}^{-1}$ and $45.46 \pm 12.35 \mathrm{mgkg}^{-1}$, respectively. The reported range is lower than $16.01-136.04 \mathrm{mgkg}^{-1}$ obtained in sediments by Dumka and Kingdom [66]. The mean THC obtained in the studied sediments is higher than $30.0 \mathrm{mgkg}^{-1}$ recommended for unpolluted sediment by WHO [60]. The high levels of THC in the studied sediments could be attributed to the activities by oil and oil related companies operating within the area. Consequently, the oxygen level of the studied river estuaries may be drastically reduced and this may be harmful to the aquatic life [67].

\subsection{Distribution of Trace Metals in sediments from the studied River Estuaries.}

Cadmium (Cd) in sediments from the studied river estuaries ranged from 0.70 to $2.11 \mathrm{mgkg}^{-1}$. This range is higher than 0.04-0.65 mgkg-1 reported in sediments from the Niger Delta Region of Nigeria by Moses et al. [68]. The mean value of Cd obtained (1.56 $\left.\pm 0.61 \mathrm{mgkg}^{-1}\right)$ is lower than $3.0 \mathrm{mgkg}^{-1}$ recommended limit for sediment by WHO [60]. Thus, Cd may not be regarded as a pollutant in sediments from the studied aquatic environments.

Copper $(\mathrm{Cu})$ concentrations in the studied river estuaries varied from 6.75 to $8.06 \mathrm{mgkg}^{-1}$. The obtained range is lower than $1.20-13.56 \mathrm{mg} / \mathrm{kg}$ reported by Alinnor and Alagoa [69]. Although, the mean obtained $\left(7.52 \pm 0.56 \mathrm{mgkg}^{-1}\right)$ is lower than 25.0 mgkg-1 $^{-1}$ commended limit for Cu in unpolluted sediment by WHO [60].

Nickel ( $\mathrm{Ni}$ ) in sediments from the studied rivers varied between 7.63 and $9.21 \mathrm{mgkg}^{-1}$ with a mean value of $8.63 \pm 0.71$ $\mathrm{mgkg}^{-1}$. The obtained range is higher than $0.4-2.3 \mathrm{mgkg}^{-1}$ reported in the region by Vincent-Akpu [70]. However, the mean value obtained is lower than $20.0 \mathrm{mgkg}^{-1}$ recommended for unpolluted sediment by WHO [60].

Iron (Fe) concentrations in sediments from the studied rivers ranged from $65.91-83.52 \mathrm{mgkg}^{-1}$ with a mean value of $83.52 \pm 8.13 \mathrm{mgkg}^{-1}$. The obtained range is lower than $6914.0-7543.0 \mu \mathrm{g} / \mathrm{g}$ reported in sediments by Howard and Olulu [71]. The mean obtained is higher than $30.0 \mathrm{mgkg}^{-1}$ recommended for Fe in unpolluted sediment by WHO [60]. Consequently, Fe may pose serious risk in the studied aquatic ecosystem as high levels of the metal could be released into these water channels. This high levels of Fe in the studied locations could be attributed to both natural and anthropogenic influence as the metal is naturally available in the study area (Onyedika [72].

Lead $(\mathrm{Pb})$ in sediments from the studied rivers ranged between 2.34 and $6.33 \mathrm{mgkg}^{-1}$. This is lower than $12.43-36.65$ $\mu \mathrm{g} / \mathrm{g}$ obtained in sediments from the Niger Delta Area of Nigeria by Ebong and Etuk [73]. The mean obtained (4.61 \pm 1.68 $\mathrm{mgkg}^{-1}$ ) is also lower than $10.0 \mathrm{mgkg}^{-1}$ recommended limit for Pb in unpolluted sediment by WHO [60]. Correspondingly, $\mathrm{Pb}$ in the studied sediments may not be regarded as a pollutant but, should be monitored since the metal is highly toxic.

The levels of zinc ( $\mathrm{Zn})$ in sediments from the studied river estuaries varied from 23.46 to $67.36 \mathrm{mgkg}^{-1}$. This is higher than 5.00 - 39.00 ppm obtained in sediments by Diayi and Gbadebo [74]. Nevertheless, mean value of Zn obtained $\left(52.0 \pm 20.24 \mathrm{mgkg}^{-1}\right)$ is lower than $123.0 \mathrm{mgkg}^{-1}$ recommended limit by WHO [60]. for unpolluted sediment. Thus, Zn as one of the macro elements may not pose any serious risk to lives exposed to sediments from the studied sources. 
Table 2 Physicochemical properties and Trace metals in surface sediments from Cross River, Imo, and Qua Iboe River Estuaries

\begin{tabular}{|l|l|c|l|c|c|c|c|c|c|}
\hline S/N & Parameter & $\begin{array}{l}\text { Cross } \\
\text { River } \\
\text { Estuary }\end{array}$ & $\begin{array}{l}\text { Imo } \\
\text { River } \\
\text { Estuary }\end{array}$ & $\begin{array}{l}\text { Qua Iboe } \\
\text { River } \\
\text { Estuary }\end{array}$ & Min & Max & Mean & SD & $\begin{array}{l}\text { Acceptable } \\
\text { Standard }\end{array}$ \\
\hline 1 & pH & 6.81 & 6.67 & 6.58 & 6.58 & 6.81 & 6.69 & 0.10 & $6.5-8.5$ \\
\hline 2 & EC & 568.10 & 554.74 & 573.62 & 554.74 & 573.62 & 565.49 & 7.93 & 1500.0 \\
\hline 3 & Nitrate & 57.54 & 65.53 & 68.28 & 57.54 & 68.28 & 63.78 & 4.56 & 40.0 \\
\hline 4 & Sulphate & 83.72 & 87.48 & 89.56 & 83.72 & 89.56 & 86.92 & 2.42 & 240.0 \\
\hline 5 & Phosphate & 2.71 & 3.29 & 3.54 & 2.71 & 3.54 & 3.18 & 0.35 & 5.0 \\
\hline 6 & THC & 17.04 & 42.48 & 61.85 & 17.04 & 61.85 & 40.46 & 18.35 & 30.0 \\
\hline 7 & Cadmium & 0.70 & 1.86 & 2.11 & 0.70 & 2.11 & 1.56 & 0.61 & 3.0 \\
\hline 8 & Copper & 6.75 & 8.06 & 7.74 & 6.75 & 8.06 & 7.52 & 0.56 & 25.0 \\
\hline 9 & Iron & 65.91 & 82.76 & 83.52 & 65.91 & 83.52 & 77.40 & 8.13 & 30.0 \\
\hline 10 & Nickel & 7.63 & 9.21 & 9.04 & 7.63 & 9.21 & 8.63 & 0.71 & 20.0 \\
\hline 11 & Lead & 2.34 & 5.17 & 6.33 & 2.34 & 6.33 & 4.61 & 1.68 & 10.0 \\
\hline 12 & Zinc & 23.46 & 65.38 & 67.36 & 23.46 & 67.36 & 52.07 & 20.24 & 123.0 \\
\hline
\end{tabular}

EC = Electrical conductivity; THC = Total hydrocarbon content; Min = Minimum; Max = Maximum; SD = Standard deviation

\section{Conclusion}

This research has shown the variations in the physicochemical properties, nutrients, total hydrocarbon content, and trace metals in water and sediments from Cross River, Imo River, and Qua Iboe River Estuary. The health and environmental implications of the parameters determined in water and sediments from the studied estuaries have been highlighted. This study revealed that, the levels of TSS, TDS, turbidity, colour, BOD, THC, $\mathrm{Cd}, \mathrm{Fe}, \mathrm{Ni}, \mathrm{Pb}$, and $\mathrm{Zn}$ in water were higher than their recommended limits. While the levels of nitrate, THC, and Fe were also higher than their acceptable limits in sediments from the studied estuaries. The study has also indicated the negative impact of crude oil and oil related activities on the quality of the studied aquatic ecosystems. Consequently, the water quality of the studied locations should be closely monitored to forestall unpleasant situation since majority of the inhabitants of the Niger Delta Region depend mainly on these water bodies for their water supply and aquatic animals.

\section{Compliance with ethical standards}

\section{Acknowledgments}

We wish to acknowledge the contributions of Staff of the Department of Soil Science and the Technologists in the Department of Chemistry, University of Uyo, Uyo. We are also grateful to the assistance rendered by the Technical Staff of Ministry of Science \& Technology, Akwa Ibom State, Nigeria for their contributions during the research. We also wish to appreciate the financial assistance granted by the Tertiary Education Trust Fund (TETFUND) through the Management of the University of Uyo, Uyo for the research.

\section{Funding Information}

This research was funded by the Tertiary Education Trust Fund (TETFUND) Institutional Based Research grant 2016 2018 merged intervention.

\section{Disclosure of conflict of interest}

We want to state clearly that, there is no conflict of interest regarding this research and this article. 


\section{References}

[1] Amadi AN. Quality Assessment of Aba River Using Heavy Metal Pollution Index. American Journal of Environmental Engineering. 2012; 2(1): 45-49.

[2] Enuneku A, Ezemonye LI, Adibeli F. Heavy metal concentrations in surface water and bioaccumulation in fish (Clarias gariepinus) of River Owan, Edo state, Nigeria. European International Journal of Science and Technology. 2013; 2(7): 31 - 39 .

[3] Omoigberale MO, Oboh IP, Erhunmwunse NO, Ezenwa IM, Omoruyi SO. An assessment of the trace metal contents of Owan River, Edo State, Nigeria. European International Journal of Science and Technology. 2014; 3(5): 88- 98.

[4] Wangboje OMI, khuabe AJ. Heavy metal content in fish and water from River Niger at Agenebode, Edo State, Nigeria. African Journal of Environmental Science and Technology. 2015; 9(3): 210 -217.

[5] Nwankwoala HO, Egesi N, Agi CC. Analysis of the water resources of kaiama area of Bayelsa State, Eastern Niger Delta. International Journal of Environmental Science and Technology. 2016; 1(2): 7-12.

[6] Nwidu LL, Oveh B, Okoriye T, Vaikosen NA. Assessment of the water quality and prevalence of water borne diseases in Amassoma, Niger Delta, Nigeria. African Journal of Biotechnology. 2008; 7(17): 2993 - 2997.

[7] WHO. WHO guidelines for drinking water quality, 4th Ed. Geneva. Volume 1, 4th Edition. $2011 ; 472$-475.

[8] Ebong GA, Etuk HS. Potability of Groundwater in Itu Local Government Area, South-South of Nigeria. International Journal of Materials Science and Applications. 2017; 6(3): 126-135.

[9] Shyamala RM, Shanti DM, Lalitha OP. Physicochemical analysis of borehole water samples of Telungupalayam area in Coimbatore District, Tamilnadu, India. E-J of Chem. 2001; 5(4): 924 -929.

[10] Adedeji OB, Okocha RC. Assessment level of heavy metal in prawn (Macrobracchium macrobrachion) and water from Epe Lagoon. Av. Env. Biol. 2011; 5(6): 1342 - 1345.

[11] WHO. World Health Organization Guideline for drinking water quality $2^{\text {nd }}$ Edition. Geneva. $2004 ; 231$ - 233.

[12] Fonge BA, Tening AS, Egbe AE, Awo EM, Focho DA, Oben PM, Asongwe GA. Fish (Arius Leudelotti valenciennes, 1840 ) as bio-indicator of heavy metals in Doula Estuary of cameroun. Afr. J. Biotechnol. 2011; 10 (73): 16581 16588.

[13] Shuhaimi MO. Metals concentration in the sediments of Richard Lake, Sudbury, Canada and sediment toxicity in an Ampipod Hyalella azteca. J. Environ. Sci. Technol. 2008; 1: 34-41.

[14] Loizidou M. Haralambous KJ, Sakellarides PO. Environmental study of the Marins part II. A study on the removal of metals from the Marianas sediment. Environ. Tech. 1992; 3: $245-252$.

[15] Birge WJ, Price JR, Shaw JA, Wigginton AJ and Hogstran Metal body burden and biological sensors as ecological indicators. Environ. Toxicol. Chem. 2000; 19: 1199- 1212.

[16] Olaifa FG, Olaifa AK, Onwude TE. Lethal and sublethal effects of copper to the African Cat fish (Clarias gariepnus). Afr. J. Biomed. Res. 2004; 7: 65-70.

[17] Oguntoke 0, Aboderin OJ, Bankole AM. Association of water-borne diseases mobility pattern and water quality in parts of Ibadan City, Nigeria. Tanzania Journal of Health Research. 2009; 11(4): 189-195.

[18] Raji MIO, Ibrahim YKE. Prevalence of waterborne infections in Northwest Nigeria: A retrospective study. Journal of Public Health and Epidemiology. 2011; 3(8): 382- 385.

[19] Udo-Inyang UC, Edem ID. Analysis of rainfall trends in Akwa Ibom State, Nigeria. J Environ Earth Sci. 2012; 2: 6070 .

[20] APHA. Standard methods for examination of water and wastewater. 20th Edition. American Public Health Association, American Water Works Association, Water Pollution Control Federation.Washington, DC. 1998.

[21] APHA. Standard Methods for the Examination of Water and Wastewater. 21st Edn., American Public Health Association/American Water Works Association, Washington, DC. USA. 2005.

[22] USEPA. Methods for collection, storage, and manipulation of sediments for chemical and toxicological analyses. Technical Manual. EPA - 823-B-01-002. US Environmental Protection Agency, Office of Water, Washington DC, USA. 2001. 
[23] USEPA. United States Environmental Protection Agency. Water Monitoring and Assesment. 5.2 Dissolved Oxygen and Biochemical Oxygen Demand. 2012.

[24] USEPA. Memorandum: Development and Adoption of Nutrient Criteria into Water Quality Standards. United State Environmental Protection Agency, Washington DC, USA. 2004.

[25] APHA. American Public Health Association. Standard methods for the examination for water and wastewater. 18.ed. Washington: APHA. 1992; 70.

[26] APHA. Standard Methods for the Examination of Water and Wastewater, 19th Edition, American Public Health Association. Washington D.C. 1995.

[27] ASTM. (American Standard of Testing Materials), Test Method for oil in water analysis, Annual Book of ASTM Standards, Vol. ASTM International U.S.A. 2003.

[28] USEPA. Risk Assessment Guidance for Superfund (RAGS). Volume I: Human Health Evaluation Manual (HHEM)— Part A, Baseline Risk Assessment. Office of Emergency and Remedial Response; Washington, DC, USA. 1989.

[29] Akpan II. Assessment of Water Quality in Imo River Estuary Using Multivariate Statistical Method. IOSR Journal of Applied Chemistry (IOSR-JAC). 2013; 4(5): 35 - 40.

[30] Wetzel RG. Limnology; Lake and River Ecosystems 3 $3^{\text {rd }}$ ed. Academic press New York. 2001; 1006.

[31] NESREA. National Environmental Standards and Regulation Enforcement Agency "1st Eleven Gazetted Regulations Federal Republic of Nigeria Official Gazette" Abuja. 2011.

[32] Anhwange BA, Agbaji EB, Gimba EC. Impact assessment of human activities and seasonal variation on River Benue, within Makurdi Metropolis. International Journal of Science and Technology. 2012; 2(5): 248 -254.

[33] Ukpong EC, Peter BU. Physico-chemical and bacteriological analyses of drinking water in Ibeno local government area of Akwa Ibom State. Nigerian Journal of Technology (NIJOTECH). 2012; 31(2): 116-127.

[34] WHO. Permissible limits of heavy metals in soil and plants (Geneva: World Health Organization), Switzerland. 1996.

[35] Ebigwai JK, Imedimfon IE, Bright HA, Olowu C, Ekanem FA. Physico-Chemical Parameters and Phytoplankton Assemblages along Spatial and Temporal Gradients in Great Kwa River, Calabar, Nigeria. International Journal of Biological Chemistry. 2014; 8: 1-20.

[36] Reza R, Singh G. Heavy metal contamination and its indexing approach for river water. Int J Environ Sci Techn. 2010; 7(4): 785-792.

[37] Ngabirano H, Byamugisha D, Ntambi E. Effects of Seasonal Variations in Physical Parameters on Quality of Gravity Flow Water in Kyanamira Sub-County, Kabale District, Uganda. Journal of Water Resource and Protection. 2016; 8: 1297-1309.

[38] Ugbaja AN, Ephraim BE. Physicochemical and bacteriological parameters of surface water quality in part of Oban Massif, Nigeria. Global Journal of Geological Sciences. 2019; 17: 13-24.

[39] Simeon EO, Idomo KBS, Chioma F. Physicochemical Characteristics of Surface Water and Sediment of Silver River, Southern Ijaw, Bayelsa State, Niger Delta Nigeria. American Journal of Environmental Science and Engineering. 2019; 3(2): 39-46.

[40] Premlata V. Multivariant analysis of drinking water quality parameters of Lake Pichhola in Udaipur, India. Biological Forum-An International Journal. 2009; 1: 97-102.

[41] Okorafor KA, Effanga EO, Andem AB, George UU, Amos DI. Spatial Variation in Physical and Chemical Parameters and Macro-Invertebrates in the Intertidal Regions of Calabar River, Nigeria. Greener Journal of Geology and Earth Sciences. 2013; 1(2): 63-72.

[42] Etesin U, Udoinyang E, Harry T. Seasonal Variation of Physicochemical Parameters of Water and Sediments from Iko River, Nigeria. Journal of Environment and Earth Science. 2013; 3(8): 96 - 110.

[43] Essien-Ibok MA, Akpan AW, Udo MT, Chude LA, Umoh IA, Asuquo IE. Seasonality in the Physical and Chemical Characteristics of Mbo River, Akwa Ibom State, Nigeria. Nigerian Journal of Agriculture, Food and Environment. 2010; 6(1\&2): 60-72.

[44] Speijers GJ. Nitrate in toxicological evaluation of certain foot additive and contaminants in food: food additive series 35. World Health Organization, Geneva. 1996; 325-360. 
[45] Isiuku BO, Enyoh CE. Pollution and health risks assessment of nitrate and phosphate concentrations in water bodies in South Eastern, Nigeria. Environmental Advances. 2020; 2: 100018.

[46] Wokoma OAF. Hydrocarbon in Water and Sediment of A Polluted Tidal Creek, Bonny River, Niger Delta, Nigeria. International Journal of Scientific \& Technology Research. 2014; 3(12): 351 - 354.

[47] Howard IC, Gabriel UU,Horsfall M. Evaluation of total hydrocarbon levels in some aquatic media in an oil polluted mangrove wetland in the Niger Delta. Applied Ecol. and Environmental Research. 2009; 7(2): 111- 120.

[48] Edokpayi JN, Odiyo JO, Popoola OE, Msagati TAM. Assessment of Trace Metals Contamination of Surface Water and Sediment: A Case Study of Mvudi River, South Africa. Sustainability. 2016; 8: 135.

[49] Genchi G, Sinicropi MS, Lauria G, Carocci A, Catalano A. The Effects of Cadmium Toxicity. Int. J. Environ Res Public Health. 2020; 17(11): 3782.

[50] Nwineewii JD, Edem CA. Determination and Toxicological Effects of Some Heavy Metals in Surface Water from the Niger Delta, Nigeria. IOSR Journal of Applied Chemistry (IOSR-JAC). 2014; 7(5): 32-36.

[51] Jonah AE, Solomon MM, Ano AO. Assessment of the physico-chemical properties and heavy metal status of water samples from Ohii Miri River in Abia State, Nigeria. Merit Research Journal of Environmental Science and Toxicology. 2015; 3(1): 001- 011.

[52] Tiwana NS, Jerath N, Singh G, Ravleen M. Heavy metal pollution in Punjab Rivers., Environmental Information System, 2005; 3(1), 3-7.

[53] Elemile 00, Raphael DO, Omole DO, Oloruntoba EO, Ajayi EO, Ohwavborua, NA. Assessment of the impact of abattoireffluent on the quality of groundwater in a residential area of Omu-Aran, Nigeria. Environmental Sciences Europe. 2019; 31(16): 1 - 10.

[54] Chennaiah JB, Rasheed MA, Patil DJ. Concentration of heavy metals in drinking water with emphasis on human health. Int J Plant Anim Environ Sci. 2014; 4(2): 205-214.

[55] Oribhabor BJ, Ogbeibu AE. Concentration of heavy metals in a Niger Delta Mangrove Creek, Nigeria. Global Journal of Environmental Sciences. 2009; 8(2): 1 - 10.

[56] Cleveland LM, Minter ML, Cobb KA, Scott AA, German VF. "Lead hazards for pregnant women and children: part 1: immigrants and the poor shoulder most of the burden of lead exposure in this country. 1 of a two-part article details how exposure happens, whom it affects, and the harm it can do". The American Journal of Nursing. 2008; 108(10): 40-49.

[57] Fosmire GJ. Zinc toxicity. Am. J. Clin. Nutr. 1990; 51(2): 225-227.

[58] Robinette CL. Zinc. Veterinary Clinics of North America Small Animal Practice. 1990; 20: 539-544.

[59] Lide DR. CRC handbook of chemistry and physics. CRC Press, Boca Raton, FL. 2006.

[60] WHO. (World Health Organization). World Health Organization meetings on the guidelines for drinking-water quality, 2-5 December 2013, Geneva, Switzerland. 2013.

[61] Adesuyi AA, Ngwoke MO, Akinola MO, Njoku KL, Jolaoso AO. Assessment of Physicochemical Characteristics of Sediment from Nwaja Creek, Niger Delta, Nigeria. Journal of Geoscience and Environment Protection. 2016; 4: 1627.

[62] Ezekiel EN, Hart AI, Abowei JFN. The Sediment Physical and Chemical Characteristics in Sombreiro River, Niger Delta, Nigeria. Research Journal of Environmental and Earth Sciences. 2011; 3: 341-349.

[63] Wokoma OAF, Friday U. The Sediment PhysicoChemical Characteristics in Sombreiro River, Rivers State, Nigeria. International Journal of Innnovation. 2017; 7(3): 16 -21.

[64] Adeolu AT, Okareh OT, Dada AO. Adsorption of chromium ion from industrial effluent using activated carbon derived from plantain (Musa paradisiaca) wastes. Am J Environ Protect. 2016; 4(1): 7-20.

[65] Seiyaboh EI, Inyang IR, Izah SC. Spatial Variation in Physico-chemical Characteristics of Sediment from Epie Creek, Bayelsa State, Nigeria. Greener Journal of Environment Management and Public Safety. 2016; 5(5): 100 103.

[66] Dumka NJ, Kingdom A. Total Hydrocarbon Concentrations (THC) in surface water, sediments and biota from Otamiri River, Rivers State, Nigeria. International Journal of Chemical Studies. 2018; 6(3): 2743-2748. 
[67] Nwineewii JD, Marcus AC. Polycyclic aromatic hydrocarbons (PAHs) in surface water and their toxicological effects in some creeks of south East Rivers State. Journal of Environmental science. 2015; 9(12): 27- 30.

[68] Moses EA, Etuk BA, Udosen ED. Spatial and Seasonal Variation in the Contamination Indices of Trace Metals in Sediment from Qua Iboe River Estuary, South-South, Nigeria. International Journal of Science and Technology. 2015; 4(11): 506 - 516.

[69] Alinnor IJ Alagoa AF. Trace Metal Distribution in Fish, Sediment and Water Samples from Nkisa River, Nigeria. British Journal of Applied Science \& Technology. 2014; 4(20): 2901-2913.

[70] Vincent-Akpu IF, Tylerb AN, Wilson C, Mackinnon G. Assessment of physico-chemical properties and metal contents of water and sediments of Bodo Creek, Niger Delta, Nigeria. Toxicological \& Environmental Chemistry. 2015; 97(2): 135144.

[71] Howard IC, Olulu BA. Metal Pollution Indices of Surface Sediment and Water from the Upper Reaches of Sombriero River, Niger Delta, Nigeria. Our Nature. 2012; 10: 206 -216.

[72] Onyedika EM. Effect of Solid Waste Source (Dumpsite Type) on Heavy Metal Contaminations in Urban Soils of Bauchi, Nigeria. American Chemical Science Journal. 2015; 9(2): 1-14.

[73] Ebong GA Etuk HS. Fractionation status and uptake potentials of trace metals in water bodies within Niger Delta Region, Nigeria. International Journal of Pure and Applied Chemistry. 13(2): 1-18.

[74] Diayi A, Gbadebo AM. Pollution Status of Metals in Sediments from Ikere, Iseyin, Opeki, Ofiki and Igangan Sections of the Ogun River Basin. IOSR Journal of Environmental Science, Toxicology and Food Technology (IOSR-JESTFT). 2014; 8(12): 53-57. 